\title{
POTENSI EKONOMI INDUSTRI PENGOLAHAN LIMBAH UDANG DI KABUPATEN PATI
}

\section{THE POTENCY OF ECONOMY FOR SHRIMP WASTE PROCESSING IN PATI DISTRICT}

\author{
Ratna Dewi Judhaswati $^{1) a) *}$ dan Herna Octivia Damayanti ${ }^{2) b)}$ \\ 1) Badan Penelitian dan Pengembangan Provinsi Jawa Timur \\ a) Jl. Gayung Kebonsari No.56, Gayungan, Surabaya. Jawa Timur \\ ${ }^{2}$ Badan Perencanaan Pembangunan Daerah Kabupaten Pati \\ b) Jl. Pati-Kudus Km. 4 Pati. 59163. Jawa Tengah \\ *Email : ratnajudhas14@yahoo.com
}

\begin{abstract}
Shrimp processing industry produces untapped waste, as result those have less economic value. Shrimp shell waste can be processed into chitinas a mixture of organic fertilizer. The research objectives were (1) to identify the type products produced from shrimp shell waste processing; (2) to estimate the products produced from shrimp shell waste processing; (3) to estimate the income and business feasibility of shrimp shell waste processing. This research uses descriptive study with a quantitative approach. The study is located in Pati district. This research was a development of the Implementation Procedure Manual Model prototype of shrimp shell waste utilization. Data analysis consists of (1) identify the type products produced from shrimp shell waste processing by descriptive; (2) estimation calculation of products produced from shrimp shell waste processing; and (3) Return-Cost analysis ( $R / C$ ratio). The results showed that (1) the products produced from shrimp shell waste processing are chitin, liquid fertilizer with $\mathrm{pH}$ 6,8 and organic fertilizer with chitin; (2) the estimated product yield was 73,926,258,753.48 kg/year; and (3) the estimated income of 592,052,603,686,220 IDR/year, profit 433,474,175,039,857 IDR/year, and $R / C$ ratio 3.734.
\end{abstract}

Kata kunci: chitin, liquid fertilizer, organic fertilizer, $R / C$ ratio, shrimp shell waste

\begin{abstract}
ABSTRAK
Industri pengolahan udang menghasilkan limbah yang belum termanfaatkan. Limbah kulit udang yang belum dimanfaatkan menyebabkan limbah kulit udang kurang memiliki nilai ekonomis. Limbah kulit udang dapat diolah menjadi kitin sebagai campuran pupuk organik. Tujuan penelitian adalah (1) untuk mengidentifikasi jenis produk hasil olahan limbah udang di Pati; (2) untuk melakukan estimasi produk yang dihasilkan dari pengolahan limbah kulit udang; dan (3) untuk melakukan estimasi pendapatan serta kelayakan usaha dari pengolahan limbah kulit udang. Penelitian ini merupakan penelitian deskriptif dengan pendekatan kuantitatif dengan lokasi penelitian di Kabupaten Pati. Penelitian ini merupakan pengembangan dari Manual Prosedur Implementasi Model prototipe pemanfaatan limbah kulit udang. Analisis data (1) estimasi produk yang dihasilkan dari pengolahan limbah kulit udang secara deskriptif; (2) perhitungan estimasi produk yang dihasilkan dari pengolahan kulit udang; dan (3) analisis Return-Cost (Rasio R/C). Hasil penelitian yaitu (1) hasil dari pengolahan limbah kulit udang adalah kitin, pupuk cair dengan pH terukur 6,8 dan pupuk organik plus kitin; (2) estimasi produk yang dihasilkan sebesar 73.926.258.753,48 kg/tahun; dan (3) estimasi pendapatan sebesar Rp592.052.603.686.220,00/tahun, profit $R p 433.474 .175 .039 .857,00 /$ tahun, dan rasio $R / C$ 3,734.
\end{abstract}

Keywords: kitin, pupuk cair, pupuk organik, rasio $R / C$, limbah kulit udang 


\section{PENDAHULUAN}

Sumber daya ikan termasuk kategori sumber daya yang dapat diperbaharui (renewable resources), sehingga sering timbul pertanyaan seberapa besar ikan yang dapat dimanfaatkan tanpa harus menimbulkan dampak negatif di masa mendatang (Damayanti, 2016). Pengelolaan sumber daya kelautan dan perikanan di Indonesia dilakukan menggunakan pendekatan blue economy. Sutriyanto (2013) menyebutkan bahwa prinsip blue economy bertujuan untuk mengefisienkan pemanfaatan sumber daya alam dengan menghasilkan lebih banyak produk turunan dan produk lain terkait.

Konsep blue economy relevan untuk diterapkan pada sektor perikanan, melalui pengembangan bisnis yang inovatif dan kreatif berdasarkan prinsip efisiensi di alam, tanpa adanya limbah yang terbuang, memunculkan kesempatan wirausaha serta menciptakan lapangan kerja, dengan kreativitas dan inovasi (Pauli, 2010). Pengembangan industri di bidang kelautan dan perikanan dengan pendekatan blue economy menjadi program utama dan unggulan Kementerian Kelautan dan Perikanan (Hidayat, 2013). Beberapa prinsip blue economy yang diterapkan pada pembangunan sektor kelautan dan perikanan antara lain sistem produksi bersih, efisien tanpa limbah, bebas pencemaran, dan tidak merusak lingkungan (Badan Riset dan Sumber Daya Manusia Kementerian Kelautan dan Perikanan Republik Indonesia, 2017).

Salah satu pengembangan industri di sektor kelautan dan perikanan yang berorientasi ekspor adalah industri pengolahan udang. Pada umumnya, udang dimanfaatkan tanpa kepala dan kulit atau tanpa kepala saja. Usaha perikanan, selain menghasilkan nilai ekonomis yang tinggi, juga ikut berperan dalam menghasilkan limbah (Syamsir, 2016). Sari \& Abdiani (2015) menyebutkan bahwa selama ini pemanfaatan udang hanya terbatas untuk kebutuhan pangan saja sedangkan limbahnya seperti kulit dan kepala udang kurang termanfaatkan dengan baik. Kautzar, dkk., (2015) menyatakan bahwa salah satu dampak dari aktivitas industri pengolahan adalah limbah yang dihasilkan oleh perusahaan.
Limbah udang berupa kulit, kepala dan ekor mengandung senyawa kimia berupa kitin, kitosan, protein, kalsium karbamat, lemak, air, abu dan lain-lain (Fachry \& Sartika, 2012). Pemanfaatan limbah udang di Indonesia masih terbatas untuk pembuatan kerupuk, petis, terasi, dan bahan pencampur pakan ternak. Limbah udang yang belum dimanfaatkan secara optimal menyebabkan limbah tersebut kurang memiliki nilai ekonomis dibandingkan dengan mengolahnya menjadi kitin dan kitosan yang bernilai ekonomis tinggi (Harjanti, 2014 \& Purwanti, 2014). Judhaswati \& Damayanti (2018b) membuat sebuah prototipe untuk pengolahan limbah kulit udang menjadi kitin, yang selanjutnya digunakan sebagai campuran pembuatan pupuk. Kitin dan kitosan banyak dibutuhkan berbagai industri modern seperti industri farmasi, biokimia, bioteknologi, biomedical, pangan, kertas, tekstil, pertanian, dan kesehatan (Nuralam, dkk., 2012).

Produksi udang tangkap di Kabupaten Pati merupakan terbesar kedua di sektor perikanan tangkap setelah ikan yaitu $7.203 \mathrm{~kg}$ sedangkan di sektor perikanan budidaya, produksi udang budidaya mencapai $255.575 .000 \mathrm{~kg}$, merupakan terbesar kedua setelah bandeng (BPS Kab. Pati, 2018). Jumlah limbah yang dihasilkan dari pengolahan udang belum tercatat secara terperinci. Belum terdapat usaha atau kegiatan industri yang mengolah limbah kulit udang di Kabupaten Pati. Limbah kulit udang biasanya hanya dibuang saja, untuk campuran makanan ternak atau campuran pembuatan terasi. Teknologi pengolahan limbah kulit udang menjadi kitin sangat berpotensi diterapkan di Kabupaten Pati. Penerapan teknologi tersebut diharapkan dapat meningkatkan nilai jual limbah kulit udang.

Dengan demikian, diperlukan sebuah kajian tentang potensi ekonomi pengolahan limbah kulit udang menjadi kitin yang dapat digunakan untuk memperkirakan pendapatan dan kelayakan usaha pengolahan ini. Tujuan penelitian ini adalah (1) mengidentifikasi jenis produk hasil olahan limbah udang di Pati, (2) mengestimasi produk yang dihasilkan dari pengolahan limbah kulit udang, dan (3) mengestimasi perolehan pendapatan serta kelayakan usaha dari pengolahan limbah kulit udang. 


\section{TINJAUAN PUSTAKA}

\section{Limbah Pengolahan Perikanan}

Limbah dapat berasal dari berbagai sumber. Sumber pembangkit limbah menurut Indrasti \& Fauzi (2009) terdiri dari lima tipe, yaitu :

1. Tipe I. Bahan baku hasil pertanian yang terdiri dari komponen utama bahan yang diubah menjadi produk dan komponen samping kotoran yang dibuang sebagai limbah

2. Tipe II. Komponen utama bahan yang tidak dapat diubah menjadi produk sehingga menjadi limbah.

3. Tipe III. Komponen utama bahan yang tidak diubah menjadi produk melainkan menjadi by product.

4. Tipe IV. Bahan pembantu dalam proses transformasi bahan baku bukan menjadi bagian produk, tetapi menjadi limbah.

5. Tipe V. Produk hasil transformasi tersebut satu ketika menjadi limbah.

Berdasarkan sifat fisiknya, limbah industri perikanan dapat dikelompokkan menjadi dua, yaitu limbah cair dan limbah padat (Irawan, 2015). Colic, et al. (2011) menyatakan bahwa tipe utama dari limbah yang ditemukan pada industri pengolahan perikanan adalah darah, kulit, kepala ikan, sisik, tulang ataupun sisa daging yang menempel pada tulang. Proses operasi utama termasuk penerimaan produk, penyortiran dan penimbangan, persiapan (pemotongan daging ikan, pemfiletan, penghilangan sisik, kulit dan kepala juga isi perut), perendaman, proses produksi seperti fermentasi dengan garam ataupun proses lain seperti pengalengan dan pembotolan, pengemasan, dan pengepakan.

Usaha kelautan dan perikanan pada umumnya menghasilkan limbah padat, seperti tulang, carapas, kulit dan kepala ikan serta limbah pakan dalam perairan. Di sisi lain, usaha kelautan dan perikanan juga menghasilkan limbah cair, misalnya air tua yang tidak dimanfaatkan pada tambak garam. Limbah berupa gas dihasilkan pada usaha perikanan tertentu seperti produksi pakan ikan. Limbah-limbah perikanan dapat diubah menjadi output yang bermanfaat untuk perkembangan ekonomi masyarakat dengan penerapan teknologi yang tepat (Luhur, dkk., 2016).

\section{Pemanfaatan Limbah Perikanan}

Besarnya potensi perikanan akan menciptakan lapangan pekerjaan, khususnya industri kecil dan kerajinan rumah tangga. Pengolahan ikan pada dasarnya memiliki fungsi untuk memaksimalkan manfaat hasil, meningkatkan nilai tambah ekonomi, dan memperpanjang daya tahan simpanan sehingga hasil produksinya sangat berpengaruh terhadap keadaan sosial ekonomi (Winarti, 2016).

Limbah industri pengolahan perikanan pada awalnya hanya memberikan pengaruh negatif pada masyarakat dan lingkungan sekitarnya, namun sekarang limbah tersebut memberikan pengaruh positif karena dapat dimanfaatkan lagi sehingga dapat memberikan keuntungan bagi masyarakat (Hikamah \& Mubarok, 2012). Pengembangan industri pengolahan limbah berpotensi untuk memperluas lapangan kerja, menumbuhkan usaha baru dalam masyarakat, dan meningkatkan pendapatan (Luhur, dkk., 2016).

Harianti (2012) menyebutkan beberapa produk hasil pengolahan limbah perikanan yaitu:

1. Tepung Ikan

Tepung ikan adalah suatu produk padat kering yang dihasilkan dengan jalan mengeluarkan sebagian besar cairan dan sebagian atau seluruh lemak yang terkandung di dalam tubuh ikan.

2. Silase Ikan

Silase ikan adalah suatu produk cair yang dibuat dari ikan-ikan utuh atau sisa-sisa industri pengolahan ikan. Ikan-ikan tersebut kemudian dicairkan menyerupai bubur oleh enzim-enzim yang terdapat pada ikanikan itu sendiri dengan bantuan asam atau mikroba yang sengaja ditambahkan.

3. Pengolahan Kitin dan Kitosan

Kitin adalah suatu polimer dari $\mathrm{N}$-Acetyl glucosamine yang terkandung dalam kepala/kulit udang dan jenis crustacea lainnya yang mempunyai struktur rantai molekul mirip dengan selulosa, sedangkan kitosan adalah turunan dari kitin.

4. Kecap Ikan

Kecap ikan adalah salah satu produk perikanan tradisional yang diolah secara fermentasi. Warnanya bening kekuningan 
sampai cokelat muda dan mengandung nitrogen. Kecap ikan sangat digemari oleh masyarakat karena selain rasanya gurih juga pembuatannya mudah dan murah. Pembuatan kecap ikan tidak memerlukan jenis ikan tertentu, dapat menggunakan ikan yang tidak bernilai ekonomis, dan limbah ikan (sisa pengolahan)

5. Terasi Ikan/Udang

Terasi adalah salah satu produk hasil fermentasi ikan atau udang yang hanya mengalami perlakuan penggaraman kemudian dibiarkan beberapa saat agar terjadi fermentasi. Pembuatan terasi ikan/ udang merupakan salah satu upaya pemanfaatan limbah padat hasil perikanan yang kualitasnya sudah tidak memenuhi syarat untuk digunakan sebagai makanan manusia atau produk sampingan dari usaha budidaya (misalnya, produksi udang rebon di tambak bandeng).

6. Kerupuk Udang

Kerupuk dapat dijadikan makanan ringan atau pelengkap makanan pokok. Limbah kepala udang dapat dimanfaatkan sebagai bahan baku dalam pembuatan kerupuk udang.

\section{Proses Pengolahan Kitin Sistem Zero Waste}

Proses pengolahan limbah kulit udang menjadi kitin (Gambar 1) adalah sebagai berikut: limbah kulit udang dicuci dengan air hingga bersih, kemudian dikeringkan di bawah sinar matahari. Limbah kulit udang yang telah bersih selanjutnya dihaluskan (dicacah) untuk mendapatkan ukuran sebesar 50 mesh.

\section{Deproteinasi}

Ekstraktor diisi dengan $7 \mathrm{~kg}$ limbah kulit udang ditambahkan larutan $\mathrm{NaOH} \quad 3,5 \%$ dengan perbandingan 10:1, kemudian dimasak dalam ekstraktor selama 1 jam pada temperatur $65^{\circ} \mathrm{C}$ (Dompeipen, dkk., 2016). Setelah direndam selama 1 jam, kemudian disaring. Air hasil pemisahan/air cucian limbah mengandung protein yang biasanya digunakan untuk pakan ternak (Judhaswati \& Damayanti, 2018b).

\section{Demineralisasi}

Limbah kulit udang hasil deproteinasi $4,2 \mathrm{~kg}$ ditambah dengan larutan $\mathrm{HCl} 1 \mathrm{~N}$ dengan perbandingan 15:1. Campuran tersebut selanjutnya dimasukkan dalam ekstraktor pada suhu $60^{\circ} \mathrm{C}$ selama 1 jam. Selanjutnya, campuran tersebut disaring sehingga diperoleh

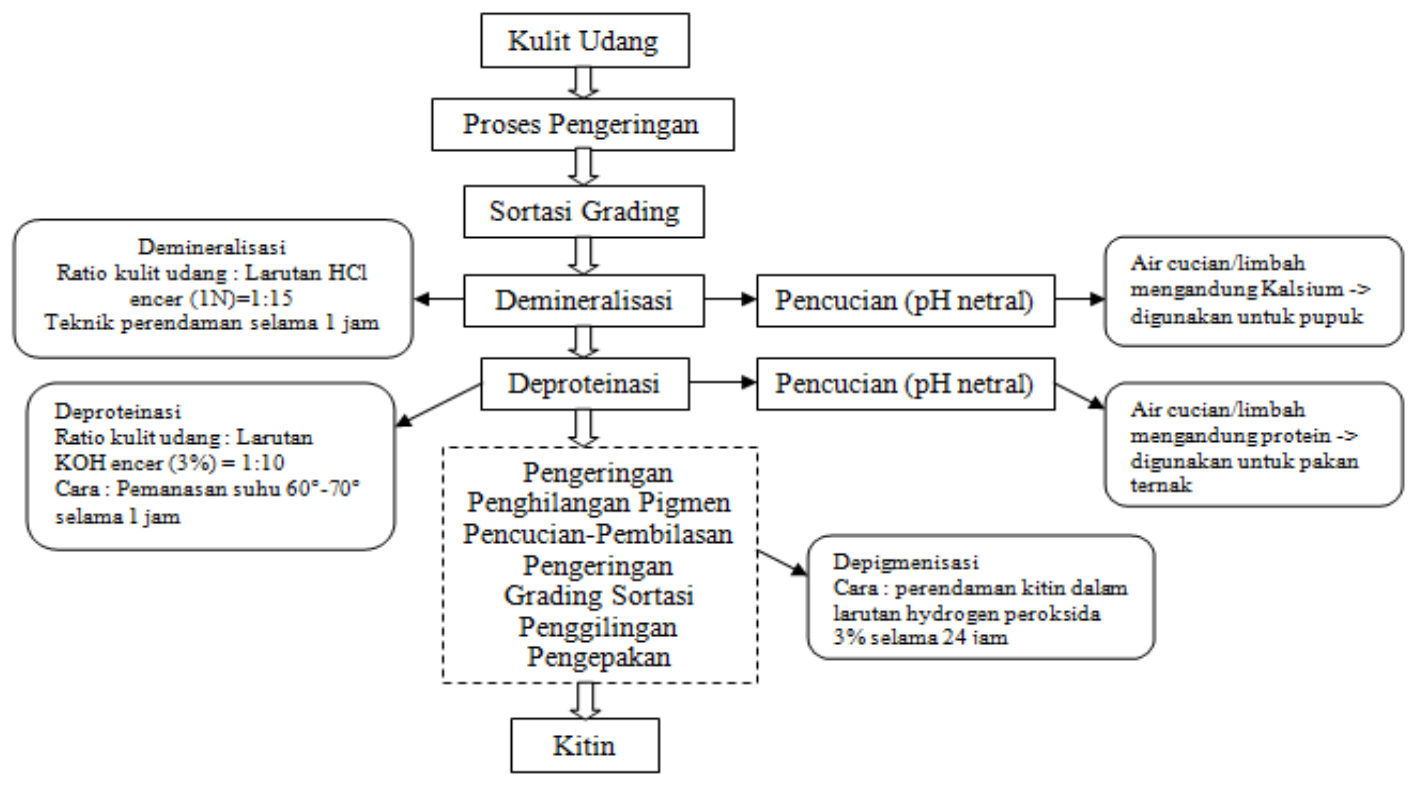

Gambar 1.

Proses Pengolahan Limbah Kulit Udang Menjadi Kitin Sistem Zero Waste

Sumber : Judhaswati \& Damayanti (2018b) 
bagian padatan dan cairan. Padatan dinetralkan dengan akuades, kemudian dikeringkan dalam ekstraktor. Padatan yang sudah dinetralkan inilah yang disebut kitin. Air hasil pemisahannya dicampurkan dengan air hasil deproteinasi dan dapat digunakan sebagai pupuk cair (Judhaswati \& Damayanti, 2018b).

\section{METODE PENELITIAN}

Penelitian ini merupakan penelitian deskriptif dengan pendekatan kuantitatif. Penelitian dilakukan pada bulan Oktober-
Desember 2018 dengan lokasi penelitian di Kabupaten Pati. Penelitian ini merupakan pengembangan dari hasil penelitian Judhaswati \& Damayanti (2018) mengenai pembuatan Manual Prosedur Implementasi Model prototipe pemanfaatan limbah kulit udang.

\section{Prototipe Teknologi Pengolahan Limbah Kulit Udang}

Berdasarkan prototipe penelitian yang dilakukan oleh Judhaswati \& Damayanti (2018) diperoleh hasil sebagai berikut:

Tabel 1.

Prototipe Produk Hasil Pengolahan Limbah Kulit Udang

\begin{tabular}{clccr}
\hline No & \multicolumn{1}{c}{ Jenis Produk } & $\begin{array}{c}\text { Bahan Baku } \\
(\mathbf{8 ~ k g )}\end{array}$ & Total & $\begin{array}{r}\text { Harga per } \\
\text { Satuan (Rp) }\end{array}$ \\
\hline 1 & Pupuk cair (liter) & & 104 & 10.000 \\
2 & Pupuk padat (kg) & & & \\
& Kitin untuk campuran & 1,4 & & \\
& Kompos & 6,3 & & \\
& Abu gosok & 6,3 & & \\
& Zeolite & 3,2 & & \\
& Dolomit & 3,2 & & \\
& Tepung kulit udang & 2,4 & & \\
& Raw phosphate & 6,3 & & \\
& hasil (kg) & & 29,1 & \\
3 & Kitin murni (kg) & & 1 & \\
\hline
\end{tabular}

Sumber : Judhaswati \& Damayanti (2018b)

Tabel 2.

Prototipe Biaya Penyusutan Investasi Pada Pengolahan Limbah Kulit Udang

\begin{tabular}{llrc}
\hline No & Jenis Investasi & Harga (Rp) & Umur Ekonomi \\
\hline 1 & Pabrik & 6.000 .000 & 25 tahun \\
2 & Dandang perebus air & 800.000 & 5 tahun \\
3 & Ember & 220.000 & 1 tahun \\
4 & Pengaduk kayu & 24.000 & 1 tahun \\
5 & Alat peniris & 56.000 & 1 tahun \\
6 & Gayung & 20.000 & 6 bulan \\
7 & Sarung tangan & 100.000 & 3 bulan \\
8 & Gelas ukur & 40.000 & 1 tahun \\
9 & Loyang pengering & 58.000 & 1 tahun \\
\hline
\end{tabular}

Sumber : Judhaswati \& Damayanti (2018b) 
Tabel 3.

Prototipe Biaya Perawatan pada Pengolahan Limbah Kulit Udang

\begin{tabular}{llrl}
\hline \multirow{2}{*}{ No } & \multicolumn{1}{c}{ Jenis Biaya } & Biaya (Rp) & Keterangan \\
\hline 1 & Perawatan gedung & 3.000 .000 & 1 tahun \\
2 & Perawatan peralatan & & \\
& - Dandang perebus air & 50.000 & 6 bulan \\
& - Ember & 20.000 & 6 bulan \\
& - Loyang pengering & 50.000 & 1 tahun \\
& - Alat peniris & 50.000 & 6 bulan \\
\hline
\end{tabular}

Sumber : Judhaswati \& Damayanti (2018b)

Tabel 4.

Prototipe Biaya Administrasi pada Pengolahan Limbah Kulit Udang

\begin{tabular}{llrl}
\hline No & \multicolumn{1}{c}{ Jenis Biaya } & Biaya (Rp) & Keterangan \\
\hline 1 & Ijin usaha & 300.000 & 1 tahun \\
2 & Pajak bangunan & 60.000 & 1 tahun \\
3 & Pajak kendaraan transport & 1.500 .000 & 1 tahun \\
\hline
\end{tabular}

Sumber : Judhaswati \& Damayanti (2018b)

Tabel 5.

Prototipe Biaya Operasional pada Pengolahan Limbah Kulit Udang

\begin{tabular}{clrr}
\hline \multirow{2}{*}{ No } & \multicolumn{1}{c}{ Jenis Biaya } & Jumlah & $\begin{array}{c}\text { Harga per Satuan } \\
\text { (Rp) }\end{array}$ \\
\hline 1 & Air (liter) & 400 & 150 \\
2 & Gas (tabung) & 2 & 18.000 \\
3 & Konsumsi (orang) & 5 & 15.000 \\
4 & Tenaga kerja (orang) & 5 & 70.000 \\
5 & Bahan tambahan & & \\
& Kulit udang (kg) & 8 & 6.000 \\
& KOH (kg) & 4,8 & 25.000 \\
& HCL (liter) & 4 & 8.000 \\
& Kompos (kg) & 6,3 & 10.000 \\
& Abu gosok (kg) & 6,3 & 9.000 \\
& Zeolite (kg) & 3,2 & 8.000 \\
& Dolomit (kg) & 3,2 & 6.000 \\
& Tepung kulit udang (kg) & 2,4 & 6.000 \\
& Raw phosphate (kg) & 6,3 & 1.000 \\
\hline
\end{tabular}

Sumber : Judhaswati \& Damayanti (2018b) 
Tabel 6.

Komponen Biaya Tetap dan Biaya Tidak Tetap Pada Pengolahan Limbah Kulit Udang

\begin{tabular}{llll}
\hline & Biaya Tetap (Fixed Cost) & \multicolumn{1}{c}{$\begin{array}{c}\text { Biaya Operasional } \\
\text { (Variable Cost) }\end{array}$} \\
\hline \multicolumn{1}{c}{ Biaya Investasi } & Biaya Pemeliharaan & Biaya Administrasi & \multicolumn{1}{c}{ Biaya Operasional } \\
\hline Pabrik & Gedung & Ijin usaha & Air \\
Peralatan & Peralatan & Pajak bangunan & Gas \\
Dandang Perebus air & Dandang perebus air & Pajak kendaraan & Konsumsi \\
Ember & Ember & Tenaga kerja \\
Pengaduk kayu & Loyang pengering & & Bahan baku \\
Alat peniris & Alat peniris & Bahan tambahan \\
Gayung & & KOH \\
Sarung tangan & & HCL \\
Gelas ukur & & Kompos \\
& & & Abu gosok \\
& & Zeolit \\
& & Dolomit \\
& & Tepung kulit udang/rajungan
\end{tabular}

\section{Analisis Return-Cost Ratio (Rasio R/C)}

Analisis Return-Cost (Rasio R/C) adalah perbandingan antara total pendapatan dan total biaya dari suatu usaha. Analisis ini dilakukan untuk menganalisis performa usaha yang dikaji melalui pendapatan usahanya (Kasmir \& Jakfar, 2009).

$\begin{aligned} \text { Profit }(\pi) & =\mathrm{TR}-\mathrm{TC} \ldots \ldots \ldots \ldots \ldots \ldots . . . . . . \\ & =(\mathrm{p} . \mathrm{C})-(\mathrm{FC}+\mathrm{VC})\end{aligned}$

Rasio $\mathrm{R} / \mathrm{C}=\mathrm{TR} / \mathrm{TC}$

Keterangan :

$\pi \quad:$ profit $(\mathrm{Rp})$

TR : total revenue / pendapatan total $(\mathrm{Rp})$

TC : total cost / biaya total (Rp)

FC : fixed cost / biaya tetap total (Rp)

$\mathrm{VC}$ : variable cost / biaya variabel total $(\mathrm{Rp})$

$\mathrm{p} \quad$ : harga ikan $(\mathrm{Rp} / \mathrm{kg})$

C : total tangkapan $(\mathrm{kg})$

Adapun kriteria hasil perhitungan ratio

$\mathrm{R} / \mathrm{C}$ adalah :

1. Jika $\mathrm{R} / \mathrm{C}$ ratio $>1$, bermakna usaha yang dijalankan mengalami keuntungan atau layak untuk dikembangkan.

2. Jika $\mathrm{R} / \mathrm{C}$ ratio $<1$, bermakna usaha tersebut mengalami kerugian atau tidak layak untuk dikembangkan.

3. Jika $\mathrm{R} / \mathrm{C}$ ratio $=1$, bermakna usaha berada pada titik impas (Break Event Point).
Biaya tetap (fixed cost) terdiri dari biaya investasi dan biaya administrasi. Biaya tidak tetap (variable cost) adalah biaya operasional.

\section{Asumsi Penelitian}

1. Potensi limbah kulit udang yang dihasilkan:

a. Data produksi udang merupakan penjumlahan dari produksi udang tangkap dan udang budidaya di Kabupaten Pati tahun 2017.

b. Estimasi udang yang diolah adalah 50\% dari produksi total udang (DKP dalam Nainggolan, dkk., 2010).

c. Estimasi limbah kulit udang yang dihasilkan adalah $60 \%$ dari total berat udang yang diolah (Chasanah \& Barus, 1994).

2. Produk yang dihasilkan:

a. Prototipe menggunakan bahan baku limbah $8 \mathrm{~kg}$.

b. Estimasi penggunaan bahan baku limbah kulit udang adalah total limbah dibagi $8 \mathrm{~kg}$.

c. Dari $1 \mathrm{~kg}$ limbah kulit udang dihasilkan 13 liter pupuk cair (hasil prototipe).

d. Pupuk padat

- Produk kitin murni yang dihasilkan yaitu sebesar 30\% dari $1 \mathrm{~kg}$ limbah kulit udang. 
- Sekitar 60\% dari kitin murni yang dihasilkan dijadikan campuran pembuatan pupuk padat.

e. $40 \%$ dari produk kitin murni langsung dijual ke pasaran.

3. Perhitungan Return-Cost Ratio (Rasio R/ C)

a. Biaya operasional setahun diperoleh dari jumlah kebutuhan dikalikan estimasi penggunaan bahan baku.

b. Biaya penyusutan investasi dan biaya perawatan setahun, diperoleh dari hasil perkalian dengan jumlah KUB (Kelompok Usaha Bersama) di Kabupaten Pati yaitu 120 KUB (Dinas Kelautan dan Perikanan Kab. Pati, 2018).

c. Pelaksana kegiatan pengolahan limbah kulit udang adalah KUB (Kelompok Usaha Bersama).

\section{HASIL DAN PEMBAHASAN}

\section{Potensi Limbah Kulit Udang di Kabupaten} Pati

Produksi udang di Kabupaten Pati berasal dari produksi udang tangkap dan udang budi daya. Data produksi udang didapatkan dari BPS Kabupaten Pati pada tahun 2018 Untuk pemanfaatannya, 50\% dijual ke pasar dalam bentuk ikan segar, $40 \%$ diolah secara tradisional dan $10 \%$ diolah secara modern (DKP dalam Nainggolan, dkk., 2010). Berdasarkan pernyataan tersebut maka diperoleh estimasi udang yang diolah sebesar 127.791.101,50 kg/tahun (Tabel 7).

Proses pengolahan udang menghasilkan limbah sebesar $60 \%$ dari berat tubuhnya (Chasanah \& Barus, 1994). Dengan asumsi tersebut, diperoleh estimasi limbah sebesar $76.674 .660,90 \mathrm{~kg}$. Limbah tersebut mengandung senyawa kitin sebesar 20-30\%. Senyawa kitin yang terkandung pada limbah kulit udang inilah yang berpotensi diolah menjadi kitin yang bernilai jual tinggi.

\section{Identifikasi Jenis Produk Hasil Olahan Limbah Udang}

Pengolahan limbah kulit udang dengan teknologi pengolahan kitin sistem zero waste. Proses pengolahan dilakukan melalui dua proses yaitu deproteinasi dan demineralisasi. Hasil dari pengolahan limbah kulit udang adalah berupa kitin dan pupuk cair dan pupuk padat (pupuk organik plus kitin) (Tabel 8).

Tabel 7.

Potensi Limbah Kulit Udang di Kabupaten Pati

\begin{tabular}{crr}
\hline Uraian & Jumlah (kg) & \multicolumn{1}{c}{ Total (kg) } \\
\hline Produksi tahun 2017 & & $255.582 .203,00$ \\
Udang tangkap & 7.203 & \\
Udang budi daya & 255.575 .000 & \\
Estimasi diolah (50\%) & & $127.791 .101,50$ \\
Limbah (60\%) & & $76.674 .660,90$ \\
\hline
\end{tabular}

Tabel 8.

Produk Hasil Pengolahan Limbah Kulit Udang di Kabupaten Pati

\begin{tabular}{clr}
\hline No & \multicolumn{1}{c}{ Jenis } & \multicolumn{1}{c}{ Jumlah (kg) } \\
\hline 1 & Pupuk organik plus kitin & $73.800 .512 .309,61$ \\
2 & Kitin & $1.150 .119,91$ \\
3 & Pupuk cair & $124.596 .323,96$ \\
& Total & $73.926 .258 .753,48$ \\
\hline
\end{tabular}


Kitin yang dihasilkan berupa serpihan yang masih basah dan perlu dijemur kemudian digiling untuk bisa dijual atau dicampurkan ke pupuk organik atau bisa juga setelah digiling langsung diaplikasikan ke sekitar tanaman. Sementara hasil sampingan proses pengolahan kulit udang menjadi kitin yang berupa cairan dijadikan pupuk cair dengan $\mathrm{pH}$ terukur 6,8 . Kitin yang dihasilkan selanjutnya dicampur dengan kompos, abu gosok, zeolite, dolomit, tepung kulit udang raw phosphate menghasilkan pupuk organik plus kitin.

\section{Estimasi Produk dari Hasil Pengolahan Limbah Kulit Udang}

Proses pengolahan limbah kulit udang menghasilkan produk berupa kitin. Proses pengolahan $1 \mathrm{~kg}$ limbah kulit udang menghasilkan kitin padat sebesar 30\% dari berat limbah kulit udang., serta menghasilkan 13 liter pupuk cair. Sebesar $40 \%$ kitin padat dijual langsung dan $60 \%$ dari produk kitin digunakan sebagai campuran pupuk dengan menambahkan bahan tambahan berupa kompos, abu gosok, zeolite, dolomit, tepung kulit udang dan raw phosphate.

Kitin dan kitosan merupakan sumber polimer terbarukan yang berasal dari cangkang crustaceae dan memiliki potensi yang besar untuk digunakan pada industri biomedis, kimia dan makanan (Vargas \& Martinez, 2010). Pemanfaatan kitin dan kitosan yang lain yaitu di sektor pertanian antara lain sebagai stimulan pertumbuhan tanaman, mekanisme pertahanan pada tanaman, coating pada benih, dan nutrien bagi tanah (Sismaraini, 2015).

Secara berurutan aplikasi kitin dan kitosan pada biomedik dan farmasi memiliki nilai tambah tertinggi dengan volume pemakaian sedikit. Selanjutnya, aplikasi kitin diikuti oleh aplikasi pada teknologi kimia, kosmetika, teknologi pangan, penjernih air, pertanian, dan tekstil. Sedangkan aplikasi yang memiliki nilai tambah terendah dengan volume pemakaian besar adalah pada teknologi kertas (Junianto dalam Sismaraini, 2015).

\section{Rasio R/C Pengolahan Limbah Kulit Udang}

Biaya pada usaha perikanan tangkap dibedakan menjadi dua yaitu biaya tetap (fixed cost) dan biaya tidak tetap (variable cost) (Ningsih, dkk., 2013). Jenis biaya tetap (fixed cost) terdiri dari biaya pemeliharaan, biaya administrasi dan biaya penyusutan. Adapun biaya tidak tetap (variable cost) yang dikeluarkan berupa biaya operasional.

Biaya tetap (fix cost) pada pengolahan kulit limbah udang sebesar Rp744.988.274,00. Biaya penyusutan selama setahun sebesar Rp126.988.274,00. Biaya pemeliharaan selama setahun sebesar Rp394.800.000,00 dan biaya administrasi selama setahun sebesar Rp223.200.000,00. Biaya tidak tetap (variable cost) pada pengolahan limbah udang berupa biaya operasional selama setahun yaitu sebesar Rp158.577.683.658.089,00 (Tabel 9). Biaya operasional paling besar adalah untuk pembelian bahan tambahan pembuatan pupuk padat yaitu raw phosphate, tepung dan dolomit. Untuk pengeluaran upah tenaga kerja tidak sebesar pembelian bahan tambahan karena proses pengolahan dominan menggunakan mesin. Total biaya pengeluaran terdiri dari pengeluaran untuk biaya tetap berupa biaya penyusutan peralatan per tahun dan pengeluaran untuk biaya variabel berupa biaya seperti pembelian bahan baku ikan, bahan penolong, dan upah tenaga kerja (Kamisi, dkk., 2017). Total pendapatan yang diperoleh selama setahun adalah sebesar Rp592.052.603.686.220,00. Keuntungan yang diperoleh selama setahun sebesar Rp433.474.175.039.857,00 dengan rasio R/C 3,734 yang berarti usaha pengolahan limbah kulit udang layak untuk dijalankan. Hal ini sesuai dengan pernyataan Mangantar, dkk., (2015) bahwa rasio $\mathrm{B} / \mathrm{C}$ atau rasio $\mathrm{R} / \mathrm{C}>1$ dapat nilai layak. Hasil penelitian Judhaswati \& Damayanti (2018a) juga menunjukkan bahwa usaha pengolahan limbah kulit udang dan rajungan memiliki rasio $\mathrm{R} / \mathrm{C}>1$ yang menunjukkan usaha yang dijalankan layak. 
Tabel 9.

Kelayakan Finansial (Rasio R/C) Pengolahan Limbah Kulit Udang di Kabupaten Pati

\begin{tabular}{|c|c|}
\hline Deskripsi & Satuan (Rp) \\
\hline Pendapatan total & 592.052 .603 .686 .220 \\
\hline Pupuk organik plus kitin & 590.404 .098 .476 .870 \\
\hline Kitin & 402.541 .969 .725 \\
\hline Pupuk cair & 1.245 .963 .239 .625 \\
\hline Biaya total & 158.578 .428 .646 .363 \\
\hline Biaya tetap & 744.988.274 \\
\hline Biaya penyusutan & 126.988 .274 \\
\hline Pabrik & 24.618 .082 \\
\hline Dandang & 16.412 .055 \\
\hline Ember & 22.566 .575 \\
\hline Pengaduk & 2.461 .808 \\
\hline Peniris & 5.744 .219 \\
\hline Gayung & 4.103 .014 \\
\hline Sarung tangan & 41.030 .137 \\
\hline Gelas ukur & 4.103 .014 \\
\hline Loyang pengering & 5.949 .370 \\
\hline Biaya pemeliharaan & 394.800 .000 \\
\hline Biaya administrasi & 223.200 .000 \\
\hline Biaya operasional & 158.577.683.658.089 \\
\hline Bahan baku & 57.505 .995 .675 \\
\hline Air & 575.059 .956 .750 \\
\hline Gas & 345.035 .974 .050 \\
\hline Konsumsi & 718.824 .945 .938 \\
\hline Tenaga kerja & 3.354 .516 .414 .375 \\
\hline $\mathrm{KOH}$ & 1.150 .119 .913 .500 \\
\hline HCL & 306.698 .643 .600 \\
\hline Kompos & 603.812 .954 .588 \\
\hline Abu gosok & 3.423 .619 .452 .511 \\
\hline Zeolit & 9.738 .295 .331 .587 \\
\hline Dolomit & 23.371.908.795.809 \\
\hline Tepung & 56.092 .581 .109 .942 \\
\hline Raw phosphate & 58.897 .210 .165 .439 \\
\hline Keuntungan (profit) & 433.474.175.039.857 \\
\hline $\operatorname{Rasio} \mathrm{R} / \mathrm{C}$ & 3,734 \\
\hline
\end{tabular}

Berdasarkan perhitungan rasio $\mathrm{R} / \mathrm{C}$ (Tabel 9) maka penerapan teknologi pengolahan limbah kulit udang di Kabupaten Pati dengan sistem zero waste layak untuk diterapkan untuk mengolah limbah kulit udang yang masih belum termanfaatkan maupun yang dimanfaatkan dengan nilai jual rendah. Penerapan teknologi pengolahan limbah kulit dengan sistem zero waste mampu meningkatkan nilai tambah dan nilai jual produk yang dihasilkan yaitu kitin, pupuk organik plus kitin dan pupuk cair. 


\section{KESIMPULAN DAN SARAN}

\section{Kesimpulan}

Kesimpulan penelitian yaitu (1) hasil dari pengolahan limbah kulit udang berupa kitin, pupuk cair dengan $\mathrm{pH}$ terukur 6,8 dan pupuk organik plus kitin; (2) estimasi produk yang dihasilkan dari pengolahan limbah kulit udang sebesar 73.926.258.753,48 kg/tahun, dan (3) estimasi perolehan pendapatan serta kelayakan usaha dari pengolahan limbah kulit udang, yaitu Rp592.052.603.686.220,00/tahun dengan estimasi keuntungan sebesar Rp433.474.175.039.857,00 per tahun dan rasio $\mathrm{R} / \mathrm{C} 3,734$.

\section{Saran}

Pemerintah Kabupaten Pati melalui Dinas Kelautan dan Perikanan perlu melakukan pengenalan, sosialisasi dan pelatihan teknologi pengolahan limbah kulit udang yang belum termanfaatkan menjadi produk yang memiliki nilai tambah/nilai jual. Sosialisasi dan pembinaan perlu dilakukan secara intensif kepada pelaku usaha pengolahan udang untuk berinovasi memanfaatkan bahan buangan/limbah dari hasil pengolahan menjadi produk yang memiliki potensi nilai jual tinggi. Upaya pemberdayaan dan pendampingan kepada Kelompok Usaha Bersama (KUB) sebagai sasaran pelatihan dan pelaku pengolahan limbah kulit udang perlu ditingkatkan.

\section{DAFTAR PUSTAKA}

Badan Pusat Statistik Kabupaten Pati. (2018). Pati dalam Angka Tahun 2017. Pati: BPS Kabupaten Pati.

Chasanah, E., Barus, H. R. (1994). Komposisi Kimia Udang dan Ikan Demersal Perairan Laut Dalam. Jurnal Penelitian Perikanan Laut, 86, 42-47.

Colic, M., Morse, W., Hicks, J., Lechter, A., Miller, J. D. (2011). Case Study: Fish Processing Plant Wastewater Treatment. Goleta. California: Clean Water Techno logy Inc.

Damayanti, H. O. (2016). Faktor-Faktor yang Mempengaruhi Produksi Ikan pada Nelayan Kecil (Studi di Desa Pecangaan Kabupaten Pati). Jurnal Litbang: Media Informasi Penelitian, Pengembangan dan IPTEK, XII (2), 83-92.
Dinas Kelautan dan Perikanan Kabupaten Pati. (2018). Data Kelompok Usaha Bersama (KUB) Kabupaten Pati. Pati: DKP Kabupaten Pati.

Dompeipen, E. J., Kaimudin, M., Dewa, R. P. (2016). Isolasi Kitin dan Kitosan dari Limbah Kulit Udang. Majalah BIAM, 12 (1), 32-38.

Fachry, A. R., Sartika, A. (2012). Pemanfaatan Limbah Kulit Udang dan Limbah Kulit Ari Singkong sebagai Bahan Baku Pembuatan Plastik Biodegradable. Jurnal Teknik Kimia, 18 (3), 1-9.

Harianti. (2012). Pemanfaatan Limbah Padat Hasil Perikanan Menjadi Produk yang Bernilai Tambah. Jurnal Balik Diwa, 3 (2), 39-46.

Harjanti, R. S. (2014). Kitosan dari Limbah Udang sebagai Bahan Pengawet Ayam Goreng. Jurnal Rekayasa Proses, 8 (1), $12-19$.

Hidayat, F. (2013). Blue Economy Solusi KKP Bangun Industri Kelautan dan Perikanan. http://www.beritasatu.com/ ekonomi/156710-blue-economy-solusikkp-bangun-industri-kelautan-danperikanan.html. Diakses tanggal 23 Oktober 2018.

Hikamah, S. R., Mubarok, H. (2012). Studi Deskriptif Pengaruh Limbah Industri Perikanan Muncar, Banyuwangi Terhadap Lingkungan Sekitar. Bioshell, 1 (1), 1-12.

Indrasti, N. S., Fauzi, A. M. (2009). Produksi Bersih. Bogor: IPB Press.

Irawan, F. (2015). Kontribusi Kapal Perikanan yang Berbasis di PPN Pelabuhan Ratu Terhadap Polusi Laut. Skripsi. Bogor: Institut Pertanian Bogor.

Judhaswati, R. D., Damayanti, H. O. (2018a). Kelayakan Usaha Pengolahan Limbah Kulit Udang dan Rajungan (Studi di Kabupaten Situbondo dan Banyuwangi Provinsi Jawa Timur). Cakrawala, 12 (2), 118-136.

Judhaswati, R. D., Damayanti, H. O. (2018b). Manual Prosedur Implementasi/PTO Model Prototipe Pemanfaatan Limbah Kulit Udang. Laporan Hasil Penelitian. Surabaya: Badan Penelitian dan Pengembangan Provinsi Jawa Timur. 
Kamisi, H. L., Lekahena, V. N. J., Hiariey, S. L. (2017). Analisis Kelayakan Usaha Pengolahan Ikan Asap di Kelurahan Faudu Kecamatan Pulau Hiri Kota Ternate. Jurnal Ilmiah Agribisnis Dan Perikanan (Agrikan UMMU-Ternate), 10 (1), 3437.

Kasmir., Jakfar. (2009). Studi Kelayakan Bisnis. Jakarta: Kencana Prenada Media Group.

Kautzar, G. Z., Sumantri, Y., Yuniarti, R. (2015). Analisis Dampak Lingkungan pada Aktivitas Supply Chain Produk Kulit Menggunakan Metode LCA dan ANP. Rekayasa Dan Manajemen Sistem Industri, 3 (1), 200-211.

Luhur, E. S., Zulham, A., \& Haryadi, J. (2016). Potensi Pemanfaatan Limbah Perikanan di Banda Aceh. Buletin Ilmiah "MARINA" Sosial Ekonomi Kelautan Dan Perikanan, 2 (1), 37-44.

Mangantar, M., Adolfina., Baramuli, D. N. (2015). Kelayakan Usaha Pengolahan Ikan Cakalang di Kota Bitung. Jurnal LPPM Bidang EkoSosBudKum, 2 (2), 73 -84 .

Nainggolan, T. Y., Sumantadinata, K., Suryani, A. (2010). Strategi Pengembangan Usaha "Nila Puff" dalam Meningkatkan Pendapatan IKM Pengolahan Hasil Perikanan pada CV. "X" di Cibinong Bogor. Manajemen IKM, 5 (2), 132-144.

Ningsih, R. S., Mudzakir, A. K., Rosyid, A. (2013). Analisis Kelayakan Finansial Usaha Perikanan Payung Jabur (Boat Seine) di Pelabuhan Perikanan Pantai Asemdoyong Kabupaten Pemalang. Journal of Fisheries Resources Utilization Management and Technology, 2 (3), 223-232.

Nuralam, E., Arbi, B. P., Prasetyowati. (2012). Pemanfaatan Limbah Kulit Kepiting menjadi Kitosan sebagai Penjernih Air pada Air Rawa dan Air Sungai. Jurnal Teknik Kimia, 18 (4), 14-20.

Pauli, G. (2010). The Blue Economy 10 Years 100 Innovations 100 Million Jobs. New Mexico: Paradigm Publications.
Peraturan Badan Riset dan Sumber Daya Manusia Kementerian Kelautan dan Perikanan Nomor 13/PER-BRSDM/2017 tentang Rencana Strategis Badan Riset dan Sumber Daya Manusia.

Purwanti, A. (2014). Evaluasi Proses Pengolahan Limbah Kulit Udang untuk Meningkatkan Mutu Kitosan yang Dihasilkan. Jurnal Teknologi, 7 (1), 8390.

Sari, D. P., Abdiani, I. M. (2015). Pemanfaatan Kulit Udang dan Cangkang Kepiting sebagai Bahan Baku Kitosan. Jurnal Harpodon Borneo, 8 (2), 142-147.

Sismaraini, D. (2015). Strategi Pengembangan Industri Kitin dan Kitosan di Indonesia. Skripsi. Bogor: Institut Pertanian Bogor.

Sutriyanto, E. (2013). Industrialisasi Kelautan Digarap Lewat Pendekatan Blue Economy. $\quad$ http://www.tribunnews.com/ bisnis/2013/12/20/industrialisasi-kelautan -digarap-lewat-pendekatan-blueeconomy. Diakses tanggal 24 Oktober 2018.

Syamsir. (2016). Pemanfaatan Limbah Hasil Perikanan. Makalah Seminar. Gorontalo: Universitas Negeri Gorontalo.

Vargas, M., Martinez, C. G. (2010). Recent Patents on Food Applications of Chitosan. Recent Patents on Food, Nutrition \& Agriculture, 121-128.

Winarti, L. (2016). Kelayakan Finansial Usaha Pengolahan Ikan Asin di Kecamatan Seruyan Hilir Kabupaten Seruyan Kalimantan Tengah. Ziraa'ah, 41 (3), 304 309.

\section{BIODATA PENULIS}

Ratna Dewi Judhaswati, lahir 16 januari 1984 di Blitar Jawa Timur. Pendidikan Sarjana Pertanian Jurusan Budi Daya Pertanian Universitas Brawijaya tahun 2008. Saat ini bekerja sebagai Peneliti di Badan Penelitian dan Pengembangan Provinsi Jawa Timur.

Herna Octivia Damayanti, lahir 6 Oktober 1985 di Kudus Jawa Tengah. Pendidikan Magister Manajemen Sumber Daya Pantai Universitas Diponegoro tahun 2016. Saat ini bekerja sebagai Peneliti di Badan Perencanaan Pembangunan Daerah Kabupaten Pati. 